\title{
Analisis Faktor yang Berhubungan dengan Perkembangan Kognitif Balita Umur 2-3 tahun di Wilayah Puskesmas Leyangan Kabupaten Semarang
}

\author{
Lia Anjar Nur Zhamaroh*, Suhartono**, Sri Achadi Nugraheni** \\ *Dinas Kesehatan Provinsi Jawa Tengah, \\ ** Fakultas Kesehatan Masyarakat, Universitas Diponegoro \\ Email:lia.anjar@gmail.com
}

\begin{abstract}
Intelligence is one of the quality of human life indicator, where cognitive abilities contribute to it. In addition to genetic factors of environmental factors, namely nutrition and stimulation, affect cognitive development of children. The purpose of this study was to analyze the factors related to cognitive development of children aged 2-3 years in the Leyangan Community Health Center, Semarang Regency.
\end{abstract}

This researh use Cross sectional design with quantitative approach. Data were collected through a questionnaire on 110 mothers of under-five year. Data analysis included univariate, bivariate analysis with Spearman correlation test, Mann-Whitney test and Chi-square, and multivariate analysis with logistic regression.

Univariate analysis showed that children under five years who had less cognitive development (41.8\%), less developmental stimulation (48.2\%), stunting (42.8\%), not participated on early chilhood education (73.8\%), and duration playing game $\geq 3$ hours / day (10\%). Family income, extended family, history of exclusive breastfeeding, nutritional status, participation in early childhood education, and developmental stimulation are significantly related to cognitive development children under five ( $p<0.05)$. Meanwhile maternal age, maternal education, maternal occupation, LBW history, and a history of preterm birth were not significantly towards the cognitive development of children under five $(p>0,05)$. The results of multivariate analysis showed that family income $(O R=$ 7,273), nutrional status $(O R=4,303)$, history of exclusive breastfeeding $(O R=$ 9,036) and developmental stimulation (OR $=$ 8,018), affected the cognitive development of children under five years.

Keywords: Cognitive development, children, developmental stimulation

\section{PENDAHULUAN}

Salah satu upaya peningkatan kualitas Sumber Daya Manusia (SDM) adalah dengan pencapaian tumbuh kembang anak secara optimal. Fase tercepat dalam pertumbuhan dan perkembangan anak terjadi pada masa balita, namun pertumbuhan otak berlangsung hanya sampai umur 18 bulan. Masa pra sekolah sering disebut sebagai masa keemasan dan masa kritis perkembangan anak, karena pertumbuhan dan perkembangan terjadi sangat cepat dan akan menentukan kualitas di masa selanjutnya. Kondisi yang mengganggu pertumbuhan dan perkembangan di masa balita akan menyebabkan terhambatnya perkembangan kognitif anak. ${ }^{1}$

Faktor yang mempengaruhi perkembangan balita terdiri dari faktor 
genetik dan faktor lingkungan. ${ }^{2}$ Faktor lain yang mempengaruhi secara positif adalah stimulasi dini dan pemberian ASI. Status sosial ekonomi yang didasarkan pada pendapatan keluarga secara tidak langsung juga mempengaruhi proses perkembangan anak. Secara signifikan perkembangan kognitif juga berhubungan dengan, usia balita, pola asuh dan status gizi balita. ${ }^{3,4}$

Gizi berperan penting dalam pertumbuhan dan perkembangan anak. Di Indonesia, spektrum malnutrisi sangat luas dan terjadi di seluruh tahap kehidupan, menurut data Riset Kesehatan Dasar (Riskesdas) tahun 2013, gangguan pertumbuhan yang dicirikan dengan status gizi tinggi badan menurut umur (stunting) pada anak di bawah usia lima tahun (balita) di Indonesia mencapai 35,7\%. ${ }^{5}$

Anak yang memiliki status gizi kurang atau buruk (underweight) berdasarkan pengukuran berat badan terhadap umur $(\mathrm{BB} / \mathrm{U})$ dan pendek atau sangat pendek (stunting) berdasarkan pengukuran tinggi badan terhadap umur (TB/U) memiliki risiko kehilangan kecerdasan Intellegence Quotion (IQ) sebesar 10-15 poin. ${ }^{6}$ Penelitian lain juga menunjukkan bahwa terdapat hubungan antara stunting dan wasting dengan prestasi kognitif dan prestasi sekolah yang buruk pada tingkat kanak-kanak lanjut. ${ }^{7}$

Pendidikan ibu yang rendah menyebabkan terbatasnya pengetahuan ibu mengenai tumbuh kembang anak dan dapat berdampak pada rendahnya kualitas pola asuh serta stimulasi yang diberikan. Penelitian sebelumnya juga menunjukkan bahwa peranan ibu selaku pengasuh dan pendidik anak di dalam keluarga dapat mempengaruhi tumbuh kembang anak..$^{8,9}$

Balita masih membutuhkan permainan yang dapat merangsang perkembangan otak yang menunjang aspek kognitif, moral, fisik, sosial emosional dan bahasa. Selain itu penelitian lain juga menunjukkan hubungan yang signifikan antara intensitas penggunaan gadget dengan perkembangan aspek bicara dan bahasa serta prestasi di sekolah. ${ }^{10,1112}$
Di Indonesia sebanyak 0,4 juta (16\%) balita mengalami gangguan perkembangan, baik perkembangan motorik halus dan kasar, gangguan pendengaran, kecerdasan kurang dan keterlambatan bicara.7 Sebanyak 779,019 jiwa anak Indonesia mengalami disabilitas intelektual (DI) dimana terjadi hambatan kognitif, afektif, psikomotor maupun sosial. ${ }^{13}$ Di Jawa Tengah angka penyandang retardasi mental di tahun 2016 mencapai 9.664 jiwa, dimana jumlahnya terus meningkat dari tahun sebelumnya. ${ }^{14}$

Gambaran aspek kognitif dapat dihubungkan dengan status gizi masyarakat. Berdasarkan hasil Riskesdas tahun 2013, prevalensi gizi kurang pada balita yaitu sebesar $19,6 \%$ terdiri dari 5,7 $\%$ gizi buruk dan $13,9 \%$ gizi kurang. 12 Di Jawa Tengah terdapat 982 kasus gizi buruk di tahun 2016, dan di Kabupaten Semarang ditemukan 66 kasus. $^{15,16}$ Di wilayah Puskesmas Leyangan, pada tahun 2016 terdapat $10,17 \%$ balita dengan status gizi kurang dan gizi buruk serta terdapat $14 \%$ balita stunting. Cakupan ASI eksklusif di tahun 2017 hanya 5,9\%. Cakupan deteksi tumbuh kembang balita juga hanya $8,37 \%$.

Hasil penelitian terdahulu banyak menemukan hubungan yang signifikan antara status gizi, stimulasi perkembangan, dan pemberian ASI eksklusif dengan perkembangan kognitif balita. Berdasarkan gambaran latar belakang yang diuraikan diatas dan informasi terkait hal tersebut yang masih sangat terbatas maka diperlukan kajian penelitiannya.

\section{METODE PENELITIAN}

Penelitian ini adalah penelitian deskriptif analitik dengan menggunakan pendekatan cross sectional. Populasi target adalah seluruh balita yang ada di wilayah Puskesmas Leyangan, sedangkan populasi terjangkau adalah balita yang berumur 2-3 tahun sebanyak 110 orang yang diambil dengan teknik purposive sampling. Penelitian dilaksanakan pada bulan JuliSeptember 2018. Analisis data 
menggunakan uji Korelasi, Mann Whitney, chi-square dan regresi logistik.

Pengumpulan data dilakukan dengan menggunakan instrumen kuesioner tertutup dan lembar observasi. Untuk kuesioner karakteristik Ibu dan balita serta stimulasi perkembangan berdasarkan Pedoman Stimulasi, Deteksi dan Intervensi Dini Tumbuh Kembang Anak tahun 2016 diisi oleh Ibu balita. Sedangkan kuesioner perkembangan kognitif balita yang mengacu pada Permendikbud No.137 tahun 201433 diisi oleh enumerator.

\section{HASIL DAN PEMBAHASAN}

Hasil analisis univariat (Tabel 1.) menunjukkan bahwa ibu balita yang berumur $<30$ tahun sebanyak 57 orang $(51,8 \%)$ dan yang berumur $\geq 30$ tahun sebanyak 53 orang $(48,2 \%)$. Mayoritas responden Ibu merupakan tamatan SMA (Sekolah Menengah Atas) sebanyak 68 orang (61.8\%) sedangkan paling sedikit adalah lulusan Sekolah Dasar (SD) sebanyak 2 orang $(1,8 \%)$.

Sebagian besar Ibu balita bekerja sebagai ibu rumah tangga (IRT) sebanyak 45 orang $(40,9 \%)$, rata-rata pendapatan keluarga responden adalah $\mathrm{Rp} 3.487 .272$ dengan batas terendah $\mathrm{Rp} 600.000$ dan tertinggi Rp 8.000.000. Lebih dari 50\% responden memiliki pendapatan yaitu sebanyakk 63 orang $(57,3 \%)$. Responden dalam penelitian ini mayoritas merupakan keluarga kecil (90\%).

Karakteristik balita dalam penelitian ini ditinjau dari riwayat BBLR, mayoritas balita lahir dengan berat badan normal (tidak BBLR) yaitu sebanyak 102 anak $(92,7 \%)$, sedangkan balita dengan riwayat kelahiran prematur sebanyak 104 anak (94,5\%) lahir aterm (cukup bulan). Balita yang mendapatkan ASI eksklusif sebanyak 63 anak $(57,3 \%)$ dan sisanya tidak mendapatkan ASI eksklusif yaitu sebanyak 47 anak $(42,7 \%)$.
Tabel 1. Hasil Analisis Univariat

\begin{tabular}{|c|c|c|c|}
\hline No & Variabel & $\mathrm{F}$ & $\%$ \\
\hline \multirow[t]{3}{*}{1} & Umur Ibu & & \\
\hline & $<30$ tahun & 57 & 51,8 \\
\hline & $\geq 30$ tahun & 53 & 48,2 \\
\hline \multirow[t]{6}{*}{2} & Pendidikan Ibu & & \\
\hline & 6 tahun (SD) & 2 & 1,8 \\
\hline & 9 tahun (SMP) & 17 & 5,5 \\
\hline & 12 tahun (SMA) & 68 & 61,8 \\
\hline & 15 tahun (D3) & 17 & 5,5 \\
\hline & 17 tahun (Sarjana) & 6 & 15,5 \\
\hline \multirow[t]{6}{*}{3} & Pekerjaan Ibu & & \\
\hline & IRT & 45 & 40,9 \\
\hline & Karyawan & 26 & 23,6 \\
\hline & Wiraswasta & 10 & 9,1 \\
\hline & Buruh Pabrik & 26 & 23,6 \\
\hline & PNS & 3 & 2,7 \\
\hline \multirow[t]{3}{*}{4} & Pendapatan Keluarga & & \\
\hline & Rendah & 50 & 45,6 \\
\hline & Cukup & 60 & 54,4 \\
\hline \multirow[t]{3}{*}{5} & Besar Keluarga & & \\
\hline & Kecil & 99 & 90 \\
\hline & Besar & 11 & 10 \\
\hline \multirow[t]{3}{*}{6} & Berat Lahir & & \\
\hline & BBLR & 8 & 7,3 \\
\hline & Tidak BBLR & 102 & 92,7 \\
\hline \multirow[t]{4}{*}{7} & Riwayat $\quad$ Kelahiran & & \\
\hline & Prematur & & \\
\hline & Prematur & 6 & 5,5 \\
\hline & Cukup bulan & 104 & 94,5 \\
\hline \multirow[t]{3}{*}{8} & Riwayat ASI Eksklusif & & \\
\hline & Tidak Eksklusif & 47 & 42,7 \\
\hline & Eksklusif & 63 & 57,3 \\
\hline \multirow[t]{3}{*}{9} & Status Gizi & & \\
\hline & Stunting & 36 & 32,7 \\
\hline & Normal & 34 & 67,3 \\
\hline \multirow[t]{3}{*}{10} & Keikutsertaan di PAUD & & \\
\hline & Tidak Mengikuti & 81 & 73,6 \\
\hline & Mengikuti & 29 & 26,4 \\
\hline \multirow[t]{3}{*}{11} & Lama Bermain Game & & \\
\hline & $\geq 3$ jam/hari & 91 & 82,7 \\
\hline & $<3 \mathrm{jam} / \mathrm{hari}$ & 19 & 17,3 \\
\hline \multirow[t]{3}{*}{12} & Stimulasi Perkembangan & & \\
\hline & Kurang & 53 & 48,2 \\
\hline & Baik & 57 & 51,8 \\
\hline \multirow[t]{3}{*}{13} & Perkembangan Kognitif & & \\
\hline & Kurang & 46 & 41,8 \\
\hline & Baik & 64 & 58,2 \\
\hline \multicolumn{2}{|c|}{ Jumlah Responden } & 110 & 100 \\
\hline
\end{tabular}

Tabel 2. menunjukkan adanya hubungan yang signifikan antara variabel pendapatan keluarga, besar keluarga dan stimulasi perkembangan dengan variabel perkembangan kognitif balita $(\mathrm{p}<0,05)$. Dan tidak ada hubungan signifikan antara umur Ibu, berat lahir, dan pendidikan ibu 
dengan perkembangan kognitif balita $(\mathrm{p}>0,05)$.

Tabel 2 Hasil Uji Korelasi

\begin{tabular}{|c|c|c|c|}
\hline \multirow{2}{*}{\multicolumn{2}{|c|}{ Variabel }} & \multicolumn{2}{|c|}{$\begin{array}{l}\text { Perkembangan } \\
\text { Kognitif }\end{array}$} \\
\hline & & Nilai $\mathrm{P}$ & $\mathrm{R}$ \\
\hline \multicolumn{2}{|l|}{ Umur Ibu } & $0,499^{\mathrm{a}}$ & $-0,065$ \\
\hline \multicolumn{2}{|c|}{ Pendapatan Keluarga } & $0,008^{\mathrm{a}}$ & 0,250 \\
\hline \multicolumn{2}{|c|}{ Pendidikan Ibu } & $0,799^{\mathrm{a}}$ & 0,025 \\
\hline \multicolumn{2}{|l|}{ Besar Keluarga } & $0,031^{\mathrm{a}}$ & 0.206 \\
\hline \multicolumn{2}{|l|}{ Berat Lahir } & $0,548^{\mathrm{a}}$ & 0,058 \\
\hline \multicolumn{2}{|l|}{ Status Gizi } & $0,016^{\mathrm{b}}$ & 0,230 \\
\hline \multicolumn{2}{|l|}{ Stimulasi } & $0,004^{\mathrm{b}}$ & 0,273 \\
\hline \multicolumn{4}{|l|}{ Perkembangan } \\
\hline \multicolumn{4}{|c|}{${ }^{a}$ Uji Spearman,${ }^{b}$ Uji Pearson } \\
\hline \multicolumn{4}{|c|}{$\begin{array}{l}\text { Tabel 3. Faktor-faktor yang Mempengaruhi } \\
\text { Perkembangan Kognitif Balita }\end{array}$} \\
\hline Variabel & $\mathrm{B}$ & $\begin{array}{l}p \\
\text { value }\end{array}$ & OR \\
\hline Status Gizi & 1,456 & 0,008 & 4,303 \\
\hline $\begin{array}{l}\text { Stimulasi } \\
\text { Perkembangan }\end{array}$ & 2,082 & 0,001 & 8,018 \\
\hline $\begin{array}{l}\text { Pendapatan } \\
\text { Keluarga }\end{array}$ & 1,984 & 0,001 & 7,273 \\
\hline $\begin{array}{l}\text { Riwayat ASI } \\
\text { Eksklusif }\end{array}$ & 2,201 & 0,000 & 9,036 \\
\hline
\end{tabular}

Hasil uji pengaruh menunjukkan bahwa terdapat pengaruh signifikan antara status gizi, stimulasi perkembangan, pendapatan keluarga, serta riwayat ASI eksklusif terhadap perkembangan kognitif balita. Sedangkan faktor umur ibu, pendidikan ibu, besar keluarga serta berat lahir tidak memiliki pengaruh yang signifikan terhadap perkembangan kognitif balita.

\section{Status Gizi dan Perkembangan Kognitif Balita}

Dalam penelitian ini, secara statistik hasil uji korelasi menunjukkan adanya hubungan antara status gizi dengan perkembangan kognitif balita $(\mathrm{p}=0,016)$. Selain itu, hasil uji regresi logistik pada Tabel 3 menunjukkan bahwa ada pengaruh yang signifikan antara status gizi dengan perkembangan kognitif balita $(p=0,008)$ dengan OR 4,303 (1,468-12,616). Artinya balita stunting berisiko mengalami perkembangan kognitif kurang 4,303 kali lebih besar daripada balita yang status gizinya normal.

penelitian ini sejalan dengan teori yang menyatakan bahwa gizi menentukan pertumbuhan dan perkembangan balita, apabila terjadi kekurangan gizi maka akan berdampak pada berkurangnya sel- sel otak, dan perubahan struktur serta fungsi otak yang berakibat pada gangguan pertumbuhan dan perkembangan. Gizi pada anak usia dini memiliki pengaruh terhadap pertumbuhan dan perkembangan kognitif, dimana pertumbuhan dan perkembangan otak paling cepat dan kritis terjadi pada periode 2 tahun pertama kehidupan, dan lobus frontalis otak akan terus berkembang hingga usia 5 tahun. ${ }^{17}$

Hasil penelitian ini juga sejalan dengan penelitian terdahulu yang dilakukan oleh Khomsan A, dkk. bahwa terdapat hubungan positif dan signifikan $(\mathrm{p}<0,01)$ antara status gizi $(\mathrm{TB} / \mathrm{U})$ dengan perkembangan kognitif anak balita di Kabupaten Subang Provinsi Jawa Barat.3 Pada penelitian ini ditemukan bahwa berdasarkan indikator $\mathrm{TB} / \mathrm{U}$, balita yang pendek (stunting) menunjukkan skor perkembangan kognitif yang lebih rendah dibandingkan dengan balita yang normal, demikian juga hal yang sama terjadi dengan indikator BB/U. Penelitian lain yang sejalan yaitu yang dilakukan oleh Rachma Purwanti yang menyatakan bahwa dengan indikator $\mathrm{BB} / \mathrm{U}$ terdapat hubungan yang signifikan antara status gizi dengan perkembangan kognitif balita $(\mathrm{p}=0,002){ }^{18}$

Penelitian di Kolkata India juga menemukan hubungan antara status gizi kronis $(\mathrm{TB} / \mathrm{U})$ dan akut $(\mathrm{BB} / \mathrm{U})$ pada anak usia sekolah. Dalam penelitian tersebut, hasil uji Pearson menyatakan adanya hubungan signifikan antara skor RCPM (Raven's Colored Progressive Matrice) yang menggambarkan tingkat kognitif balita dengan status gizi, baik menggunakan indikator $\mathrm{TB} / \mathrm{U}, \mathrm{BB} / \mathrm{U}$, ataupun IMT dengan $\mathrm{P}$ value $<0,001$. 
Kondisi status gizi kronis dan akut menunjukkan penampilan kognitif yang lebih rendah dibandingkan pada anak yang status gizinya normal. Dampak gizi kurang pada anak usia dini akan dimanifestasikan pada kemampuan kognitif di usia yang lebih dewasa, yaitu terdeteksi pada saat anak sudah bersekolah. ${ }^{19}$

Penelitian yang dilakukan di Vietnam menunjukkan bahwa, pada peningkatan 1 (satu) standar deviasi pada indikator $\mathrm{TB} / \mathrm{U}$ akan meningkatkan ketrampilan bahasa anak sebesar 0,11 standar deviasi. ${ }^{20}$ Penelitian serupa di Peru juga menunjukkan bahwa peningkatan hasil pengukuran indikator TB/U sebesar satu standar deviasi berhubungan dengan adanya peningkatan skor pada Peabody Picture Vocabulary Test (PPVT) sebesar 2,35 poin. Hal ini berarti anak yang berbadan lebih tinggi di usianya memiliki kosa kata yang lebih banyak dibandingkan anak yang lebih pendek. Anak stunting memiliki kosakata yang terbatas dan tingkat intelegensi yang rendah di usia sekolah. ${ }^{21}$

\section{Stimulasi Perkembangan \\ Perkembangan Kognitif Balita}

dan

Stimulasi adalah bagian dari intervensi dini yang bermanfaat bagi tumbuh kembang anak dan merupakan bentuk pendidikan dalam rangka mengembangkan kemampuan kognitif, fisik, motorik, serta sosial emosi anak. Anak yang mendapat stimulasi terarah dan teratur akan lebih cepat berkembang dibandingkan anak yang kurang/tidak mendapat stimulasi. ${ }^{2}$

Uji korelasi Spearman menunjukkan adanya hubungan signifikan antara stimulasi perkembangan dengan perkembangan kognitif balita $(\mathrm{p}=0,002$ dan nilai $r=0,287$ ) walaupun dengan tingkat kekuatan hubungan yang lemah. Hasil uji chi-square juga menunjukkan hubungan bermakna antara stimulasi perkembangan dengan perkembangan kognitif balita $(p=0,039)$. Semakin baik stimulasi yang diberikan oleh ibu maka, perkembangan kognitif balita semakin baik. Proporsi perkembangan kognitif kurang pada balita yang stimulasinya kurang, lebih besar dibandingkan dengan balita yang mendapatkan stimulasi baik yaitu sebesar $52,8 \%$.

Hasil penelitian ini sejalan dengan penelitian yang dilakukan oleh Rachma Purwanti di kota Semarang, bahwa stimulasi psikososial berhubungan signifikan dengan perkembangan kognitif balita $(p=0,007) .80$ Demikian halnya dengan penelitian yang dilakukan oleh Khomsan, dkk juga menyatakan bahwa stimulasi psikosial juga berhubungan positif terhadap perkembangan kognitif balita pada anak petani dan bukan petani $(\mathrm{p}<0,01){ }^{1,18}$

Pemberian stimulasi akan lebih efektif apabila memperhatikan kebutuhankebutuhan anak sesuai dengan tahap-tahap perkembangannya. Penelitian menemukan bahwa stimulasi psikososial berhubungan positif dan signifikan dengan perkembangan kognitif anak. ${ }^{22}$ Stimulasi yang diberikan dapat berupa verbal, auditori, visual, taktil, dan lain-lain.

Stimulasi perkembangan yang digunakan sebagai dasar pengukuran pada penelitian ini merujuk pada pedoman SDIDTK Kementerian Kesehatan RI. Aspek yang distimulasi meliputi aspek motorik kasar, motorik halus, bahasa dan personal sosial. ${ }^{23}$

Analisis regresi logistik menunjukkan bahwa terdapat pengaruh antara stimulasi perkembangan dengan perkembangan kognitif balita $(\mathrm{p}=0,001)$. Nilai OR 8,018 artinya peluang balita yang kurang mendapatkan stimulasi 8,018 kali lebih besar untuk mengalami perkembangan kognitif kurang dibandingkan balita yang stimulasinya baik.

\section{Pendapatan Keluarga dan Perkembangan Kognitif Balita}

Stimulasi adalah bagian dari intervensi dini yang bermanfaat bagi tumbuh kembang anak dan merupakan 
bentuk pendidikan dalam rangka mengembangkan kemampuan kognitif, fisik, motorik, serta sosial emosi anak. Anak yang mendapat stimulasi terarah dan teratur akan lebih cepat berkembang dibandingkan anak yang kurang/tidak mendapat stimulasi. ${ }^{2}$

Uji korelasi Spearman menunjukkan adanya hubungan signifikan antara stimulasi perkembangan dengan perkembangan kognitif balita $(\mathrm{p}=0,002$ dan nilai $r=0,287$ ) walaupun dengan tingkat kekuatan hubungan yang lemah. Hasil uji chi-square juga menunjukkan hubungan bermakna antara stimulasi perkembangan dengan perkembangan kognitif balita $(\mathrm{p}=0,039)$. Semakin baik stimulasi yang diberikan oleh ibu maka, perkembangan kognitif balita semakin baik. Proporsi perkembangan kognitif kurang pada balita yang stimulasinya kurang, lebih besar dibandingkan dengan balita yang mendapatkan stimulasi baik yaitu sebesar $52,8 \%$.

Hasil penelitian ini sejalan dengan penelitian yang dilakukan oleh Rachma Purwanti di kota Semarang, bahwa stimulasi psikososial berhubungan signifikan dengan perkembangan kognitif balita $(p=0,007) .80$ Demikian halnya dengan penelitian yang dilakukan oleh Khomsan, dkk juga menyatakan bahwa stimulasi psikosial juga berhubungan positif terhadap perkembangan kognitif balita pada anak petani dan bukan petani $(\mathrm{p}<0,01) .{ }^{1,18}$

Pemberian stimulasi akan lebih efektif apabila memperhatikan kebutuhankebutuhan anak sesuai dengan tahap-tahap perkembangannya. Penelitian menemukan bahwa stimulasi psikososial berhubungan positif dan signifikan dengan perkembangan kognitif anak. ${ }^{22}$ Stimulasi yang diberikan dapat berupa verbal, auditori, visual, taktil, dan lain-lain.

Stimulasi perkembangan yang digunakan sebagai dasar pengukuran pada penelitian ini merujuk pada pedoman SDIDTK Kementerian Kesehatan RI. Aspek yang distimulasi meliputi aspek motorik kasar, motorik halus, bahasa dan personal sosial. ${ }^{23}$

Analisis regresi logistik menunjukkan bahwa terdapat pengaruh antara stimulasi perkembangan dengan perkembangan kognitif balita $(\mathrm{p}=0,001)$. Nilai OR 8,018 artinya peluang balita yang kurang mendapatkan stimulasi 8,018 kali lebih besar untuk mengalami perkembangan kognitif kurang dibandingkan balita yang stimulasinya baik.

\section{Riwayat ASI Eksklusif dan Perkembangan Kognitif Balita}

Hasil uji beda rerata (Mann Whitney) menunjukkan bahwa terdapat hubungan signifikan antara variabel riwayat ASI eksklusif dengan perkembangan kognitif balita $(P$ value $=0,011)$. Demikian juga dari hasil uji beda proporsi antara variabel riwayat ASI eksklusif dengan perkembangan kognitif balita menunjukkan hubungan yang signifikan dengan $P$ value $=0,000$. Hal ini sesuai dengan penelitian di Inggris yang memaparkan bahwa durasi menyusui yang lebih lama akan berdampak signifikan pada kenaikan nilai tes yang rendah. Hal ini sejalan dengan penelitian lain bahwa bahwa intervensi yang meningkatkan tingkat menyusui akan meningkatkan tidak hanya kesehatan anak-anak, tetapi juga keterampilan kognitif mereka, dan mungkin juga pengembangan non-kognitif mereka. ${ }^{17,24,25}$ Penelitian lain oleh Ulfa Farrah Lisa menyatakan bahwa terdapat hubungan signifikan antara pemberian ASI eksklusif dengan perkembangan motorik balita $(\mathrm{p}=0,000){ }^{26}$

Protein istimewa dari ASI yaitu taurin yang berfungsi untuk nutrisi otak dan syaraf,serta lactoferin yang berfungsi menghasilkan vitamin untuk pertumbuhan. Lemak ASI mudah dicerna sehingga mudah diserap oleh bayi, karena mengandung enzim lipase. Lemak utama pada ASI adalah omega-3, omega-6, Docosehaxaenoic Acid (DHA), dan Arachidonic Acid (AHA), yang merupakan 
asam lemak esensial untuk pembentukan serabut syaraf. ${ }^{27,28}$

Hasil uji multivariat menunjukkan bahwa riwayat pemberian ASI eksklusif menunjukkan pengaruh signifikan terhadap perkembangan kognitif balita $(\mathrm{p}=0,000)$. Dengan nilai OR 9,036 artinya balita yang tidak mendapatkan ASI eksklusif mempunyai risiko mengalami perkembangan kognitif kurang 9,036 kali lebih besar dibandingkan pada balita dengan riwayat ASI eksklusif.

\section{KESIMPULAN}

Karakteristik Ibu yaitu umur, pendidikan, dan pekerjaan bukan merupakan faktor yang berhubungan dengan perkembangan kognitif balita umur 2-3 tahun di wilayah Puskesmas Leyangan Kabupaten Semarang ( $p>0,05)$. Sedangkan pendapatan dan besar keluarga merupakan faktor yang berhubungan dengan perkembangan kognitif balita $(\mathrm{p}<0,05)$. Karakteristik balita yaitu riwayat BBLR dan riwayat kelahiran prematur bukan merupakan faktor yang berhubungan dengan perkembangan kognitif balita $(p>0,05)$, sedangkan riwayat pemberian ASI eksklusif merupakan faktor yang berhubungan dengan perkembangan kognitif balita $(\mathrm{p}<0,05)$.

Faktor yang berpengaruh terhadap perkembangan kognitif balita adalah pendapatan keluarga $(\mathrm{OR}=7,273)$, riwayat pemberian ASI eksklusif $(\mathrm{OR}=9,036)$, status gizi $(\mathrm{OR}=4,303)$, dan stimulasi perkembangan $(\mathrm{OR}=8,018)$.

\section{UCAPAN TERIMA KASIH}

Penulis mengucapkan terima kasih kepada Dinas Kesehatan Kabupaten Semarang dan Puskesmas Leyangan Kabupaten Semarang atas ijin yang diberikan untuk melaksanakan penelitian ini. Penulis juga mengucapkan terima kasih kepada para responden yang telah bersedia berpartisipasi pada penelitian ini.

\section{DAFTAR PUSTAKA}

1. Khomsan, A. Anwar, F.Warsito, O. Hernawati N. Growth-cognitivedevelopment-and-psychosocialstimulation-of-preschool-children-inpoor-farmer-non-farmerhouseholds.pdf. 2013; 325-337.

2. Soetjiningsih. Tumbuh Kembang Anak. Jakarta: Jakarta: EGC, 2005.

3. Salimar.Hastuti, D. Latifah M. Hubungan Beban Kerja, Pengetahuan Ibu, dan Pola Asuh Psikososial Dengan Perkembangan Kognitif Anak Usia 2-5 Tahun Padaa Keluarga Miskin. J Ilmu Kel 2011; 34: 39-49.

4. Santrock J. Educational Pshycology. 5th ed. New York: New York: Mc.Graw Hill, 2014.

5. Kementerian Kesehatan. Riset Kesehatan Dasar. Jakarta, 2013.

6. Barker L. Introduction:The Window of Opportunity. J Nutr 2007; 37: 8-9.

7. Rahmaulina, N. Hastuti D. Relation Between Mother's Knowledge on Nutrition and Child's Growth Development to Psychosocial Stimulation and Cognitive Development of Children Aged 2-5 Years Old. J Ilmu Kel dan Konsum.

8. Dodik, B.Herawati T. Peran Stimulasi Orang Tua terhadap Perkembangan Anak Balita. J Gizi Masy 2008; 1: 6377.

9. Grantham-Mc.Gregor $\mathrm{S}$ et al. Developmental Potential in the First 5 Year for Children in Developing Countries. Lancet 2007; 369: 60-70.

10. Warisyah Y. Pentingnya " Pendampingan Dialogis " Orang Tua Dalam Penggunaan Gadget Pada Anak Usia Dini. Pros Semin Nas Pendidik "Inovasi Pembelajaran untuk Pendidik Berkemajuan 2015; 2016: 130-138.

11. Samec J. Advantages and Disadvantages of Information Communication Technology Usage for Four-Year-Old Children and The Consequences of Its Usage for The Children's Development. Int $J$ 
Humanit Soc Sci 2012; 2: 54-58.

12. Manumpil, B. Ismanto, Y. Onibala F. Hubungan Penggunaan Gadget dengan Tingkat Prestasi Siswa di SMAN 9 Manado. ejournal Keperawatan; 3.

13. Retnaningsih I, Hidayat R. Representasi Sosial tentang Disabilitas Intelektual pada Kelompok Teman Sebaya. 2012; 39: 13-24.

14. Kemendikbud. Statistik sekolah luar biasa (slb) 2016/2017. 2017.

15. Profil Dinas Kesehatan Provinsi Jawa Tengah. 2016.

16. Profil Dinas Kesehatan Kabupaten Semarang. 2016.

17. Bryan, J. Osendarp, S. Hughes D. Nutrients for Cognitive Development in School Aged Children. Nutr REv 2004; 62: 295-306.

18. Purwanti R. Hubungan Status Gizi, Stimulasi Psikososial, dan Keikutsertaan PAUD dengan Perkembangan Kognitif Balita di Kota Semarang (Tesis). Semarang: Universitas Diponegoro, 2015.

19. Ghosh S, Chowdhury SD, Chandra AM, et al. Grades of undernutrition and socioeconomic status influence cognitive development in school children of Kolkata. Am $J$ Phys Anthropol 2015; 156: 274-285.

20. Nguyen P. Influence of Early Child Nutritional Status and Home Environment on Child Development in Vietnam. Fed Am Soc Exp Biol J; 30.

21. Alder S. Impact of Early and Concurent Stunting on Cognition. J Matern Child Nutr 2011; 7: 397-409.

22. Zetlin M. Nutritional Resilence in Hostile Environment: POsitive DEviance in Child Nutrition. Nutr Rev 1991; 49: 259-268.

23. Kementerian Kesehatan. Stimulasi, deteksi dan intervensi dini tumbuh kembang anak (sosialisasi buku pedoman pelaksanaan DDTK di tingkat pelayanan kesehatan dasar), Jakarta. 2012; 122.

24. Mc Afee, A. Mulhern, M. McSorley, E. Wallace, J. Bonham M. Intakes and adequacy of pottentially important nutrients for cognitive development among 5 years old children in the Seychelles Child DEvelopment and Nutrition Study. Public Health Nutr 2012; 15: 1670-1677.

25. Bernard, J. De Agostini, M. Forhan A. Breastfeeding Duration and Cognitive Development at 2 and 3 years of age in the Eden Mother Child Cohort. $J$ Pediatr 2013; 163: 36-42.

26. Lisa UF. Hubungan Pemberian ASI Ekslusif dengan Perkembangan Motorik Kasar Balita di Kelurahan Brontokusuman Kecamatan Mergangsan Yogyakarta. J Ilm STIKES U'Budiyah 2012; 1: 1-7.

27. Roesli U. Mengenal ASI Eksklusif. Jakarta: Jakarta: Trubus Agriwidya, 2013.

28. Proverawati R. Kapita Selekta ASI dan Menyusui. Yogyakarta: Yogyakarta: Nuha Medika, 2013. 